\title{
Reforming Russian legal mechanisms for the rehabilitation of the debtor through the prism of comparative studies
}

\author{
Inna Vladimirovna Ershova, Tatiana Petrovna Shishmareva, Ekaterina Evgenievna Enkova, \\ Olga Viktorovna Sushkova ${ }^{1}$, and Sergey Sergeevich Galkin \\ Kutafin Moscow State Law University, Moscow, Russia
}

\begin{abstract}
The purpose of this study is to formulate the main elements of the legal model for reforming the Russian insolvency legislation based on the analysis of regulatory decisions of foreign legal orders, where the idea of the sanation of the debtor and its enterprise is successfully implemented. Comparative-legal and sociological methods of scientific cognition were used as a methodological basis. The results of the work were the analysis of the experience of the United States and Germany, the legislation of which contains effective models for resolving the conflict between the debtor and its creditors within the framework of sanation. In addition, the authors formulated and substantiated the conclusion regarding the urgent need to change the Russian concept of insolvency legislation through the transition from the liquidation of insolvent entities, mainly to the sanation of debtors or its enterprises. The authors also proposed key elements of a possible legal model for such reform, including establishing a unified restructuring competitive procedure for debtors - legal entities; preserving the powers of the debtor in the course of this procedure to handle its corporate management; solving the most significant issues of the restructuring procedure mainly by reaching an agreement between the main participants in the procedure - the debtor, the beneficiaries of the debtor and various classes of creditors. The novelty of the work lies in formulating the problem and substantiating the requirement to transform the Russian legal mechanisms for the rehabilitation of the insolvent debtor, taking into account the legal solutions presented, first of all, in American and German insolvency legislation.
\end{abstract}

Keywords: market economy, legislation, comparative law

\section{Introduction}

The shortcomings of the Russian insolvency legislation and, as a consequence, the practice of its application negatively affect the development of a market economy in the country, which prompts the legislator to consider developing the optimal ways to improve it. The reform of legislation in this area abroad has led to the widespread use of rehabilitation procedures.

${ }^{1}$ Corresponding author: ovsushkova@mail.ru 
The main mission of the insolvency institution in a market economy is to maintain its stability. The main tendency in the development of this institution in foreign legal orders is the sanation of the debtor or its enterprise in various economic and legal forms on the basis of a balance of interests between the debtor, including its beneficiaries, and creditors [1]. Meanwhile, the practice of applying the Federal Law dated October 26, 2002 No. 127-FZ "On Insolvency (Bankruptcy)" (hereinafter referred to as the bankruptcy law) testifies, firstly, to the fundamental lack of demand for rehabilitation competitive procedures among Russian entrepreneurs (Thus, for the period from 2007 to the first half of 2013 inclusive, a total of 103,661 recovery and liquidation procedures were introduced in Russia, of which external management -5368 , or $5.2 \%$, financial recovery -466 , or $0.4 \%$. The situation has not changed at present, which indicates a pronounced trend. According to the Statistical Bulletin of the EFRSB in 2020, the courts introduced 173 external management and financial recovery procedures, or $1.7 \%$ of all procedures (excluding supervision), compared to 228 procedures $(1.8 \%$ ) in 2019); secondly, the extraordinary spread of the vicious practice from all points of view of filing the debtor's application at that stage of the financial crisis when its rehabilitation becomes impossible, and the only applied procedure is naturally competitive proceedings with the subsequent termination of its activities as a subject of law. These circumstances are due to the general imperfection of the legal mechanisms for the rehabilitation of the insolvent debtor in the Russian legal order, the legally unbalanced broad autonomy of majority creditors in competitive procedures, which lays the foundations for a future conflict between creditors and the debtor, as well as between individual groups of creditors in competitive procedures. Taking into account the above-mentioned, in order to develop optimal legal models for reforming Russian legislation and the practice of its application, it is required to study foreign experience in regulating rehabilitation procedures in relation to the insolvent debtor, as well as resolving the debtor's conflict with its creditors.

\section{$2 \quad$ Methods}

The methodological basis of the research was formed by the following methods of scientific cognition: analysis, synthesis, deduction, interpretation, modeling, as well as comparative-legal and sociological methods.

No scientific cognition, including jurisprudence, can exist within national boundaries but assumes the exchange of scientific research results [2], the study of the most cited publications of foreign authors [3]. It is equally important to study advanced foreign legislation [4], for example, the specifics of corporate responsibility in the situation of insolvency [5], the best practices [6], including the experience of judges in conducting reorganization procedures in the bankruptcy process [7], even the side effects of bankruptcy [8], to borrow them, introduce them into the Russian legal order, and form the vector of the development of Russian competition law. Taking this approach into account, the use of the comparative-legal method is due to the manifestation of its functional purpose as a method of forming legal models for reforming national legal institutions.

In February 2021, the authors conducted a sociological survey "Reforming bankruptcy procedures" using a questionnaire method, in which, in the course of a targeted sample, 53 students of the 1st year of master's degree at the Kutafin Moscow State Law University (MSAL) acted as the respondents. This research should be characterized as applied one; one-time, point, search (investigative); express research. 
It should be noted that integrating various research methods gives a synergistic effect at all stages of the development of relations in the field of bankruptcy: from predicting [9] and analyzing the risks of insolvency [10] to applying rehabilitation and liquidation procedures.

\section{$3 \quad$ Results}

In the Methods section, it was already mentioned that the authors conducted a sociological study with the participation of the master's degree students of the Kutafin Moscow State Law University (MSAL). The results of the survey for the positions of interest to the authors are shown in Table 1.

Table 1. Reforming bankruptcy procedures.

\begin{tabular}{|c|c|c|c|}
\hline \multirow{2}{*}{ Question } & \multicolumn{3}{|c|}{ Level: master's degree / form of study } \\
\hline & $\begin{array}{c}\text { Intramural } \\
22 \text { people }\end{array}$ & $\begin{array}{c}\text { Extramura } \\
1 \\
31 \text { people }\end{array}$ & $\begin{array}{c}\text { Total } \\
53 \text { people }\end{array}$ \\
\hline $\begin{array}{l}\text { 1. Should the bankruptcy law regulate in detail the } \\
\text { pre-trial procedures aimed at preventing } \\
\text { bankruptcy? } \\
\text { A) Yes } \\
\text { B) No }\end{array}$ & $\begin{array}{l}\text { A } 14 \\
\text { B } 8\end{array}$ & $\begin{array}{l}\text { A } 24 \\
\text { B } 7\end{array}$ & $\begin{array}{l}\text { A } 38 \\
\text { B } 15\end{array}$ \\
\hline $\begin{array}{l}\text { 2. In terms of its target, what should be the } \\
\text { procedure for "entering" the bankruptcy process? } \\
\text { A) Neutral } \\
\text { B) Rehabilitation } \\
\text { C) Liquidation }\end{array}$ & $\begin{array}{l}\text { A } 8 \\
\text { B } 14 \\
\text { C- }\end{array}$ & $\begin{array}{l}\text { A } 8 \\
\text { B } 22 \\
\text { C } 1\end{array}$ & $\begin{array}{l}\text { A } 16 \\
\text { B } 36 \\
\text { C } 1\end{array}$ \\
\hline $\begin{array}{l}\text { 3. How many procedures should there be in the } \\
\text { bankruptcy law aimed at restoring the debtor's } \\
\text { solvency? } \\
\text { A) One is enough } \\
\text { B) More than one }\end{array}$ & $\begin{array}{l}\text { A } 10 \\
\text { B } 12\end{array}$ & $\begin{array}{l}\text { A } 7 \\
\text { B } 24\end{array}$ & $\begin{array}{l}\text { A } 17 \\
\text { B } 36\end{array}$ \\
\hline $\begin{array}{l}\text { 4. Is it necessary to change the goals of } \\
\text { rehabilitation procedures for legal entities and } \\
\text { indicate among them the sanation of the debtor's } \\
\text { enterprise, as in Germany? } \\
\text { A) Yes } \\
\text { B) No }\end{array}$ & $\begin{array}{l}\text { A } 15 \\
\text { B } 7\end{array}$ & $\begin{array}{l}\text { A } 21 \\
\text { B } 10\end{array}$ & $\begin{array}{l}\text { A } 36 \\
\text { B } 17\end{array}$ \\
\hline $\begin{array}{l}\text { 5. Do you allow the use, as in Germany, of a single } \\
\text { bankruptcy procedure, the purpose of which is } \\
\text { determined by the creditors? } \\
\text { A) Yes } \\
\text { B) No }\end{array}$ & $\begin{array}{l}\text { A } 3 \\
\text { B } 19\end{array}$ & $\begin{array}{l}\text { A } 5 \\
\text { B } 26\end{array}$ & $\begin{array}{l}\text { A } 8 \\
\text { B } 45\end{array}$ \\
\hline $\begin{array}{l}\text { 6. Is it permissible to introduce bankruptcy } \\
\text { procedures without the control by the } \\
\text { court-appointed receiver? } \\
\text { A) Yes } \\
\text { B) No } \\
\text { C) For some procedures, it is permissible }\end{array}$ & $\begin{array}{l}\text { A - } \\
\text { B } 17 \\
\text { C } 5\end{array}$ & $\begin{array}{l}\text { A } 15 \\
\text { B } 16 \\
\text { C - }\end{array}$ & $\begin{array}{l}\text { A } 15 \\
\text { B } 33 \\
\text { C } 5\end{array}$ \\
\hline
\end{tabular}

Source: compiled by the authors. 
The overwhelming majority $(71.7 \%)$ of respondents believe that the mere mention of pre-trial procedures in the bankruptcy law is clearly not enough to successfully prevent the bankruptcy of debtors, while its more detailed regulation will help to strengthen the trend for the recovery of companies. According to $67.9 \%$ of respondents, bankruptcy proceedings should begin in court with the rehabilitation procedure. For comparison, only $1.9 \%$ of the respondents were in favor of the liquidation procedure for "entering" the bankruptcy process. More than two thirds $(67.9 \%)$ of the survey participants support the normative consolidation of the possibility of choosing one of several rehabilitation procedures. Many $(67.9 \%)$ respondents admit a change in the goals of rehabilitation procedures and indicate among them the sanation of the debtor's enterprise. At the same time, the absolute majority (84.9\%) of the respondents deny the possibility of creditors defining the goal of a single bankruptcy procedure in the absence of its clear regulation by the legislator. Another possible novelty - the introduction of bankruptcy procedures without the control by the court-appointed receiver also received negative assessments by $62.3 \%$ of the respondents.

\section{Discussion}

According to scientists, the practical area of world jurisprudence is subject to internationalization processes [11]. The evolution of the competition law confirms this conclusion. The US legal order in terms of regulating the procedures for restructuring the insolvent debtor acts as a source of legal decisions in reforming competitive procedures for most foreign legal orders. Thus, the Chapter 11 of the US Bankruptcy Code allows both to restructure debts to the debtor as an operating enterprise, and to liquidate the debtor as an economic entity, having preliminary distributed assets taking into account the creditor and other requirements. One of the legal means of ensuring the restructuring model established in the norms of the Chapter 11 of the Code is the "debtor-in-possession" structure - the corporate management of the debtor retains the management and control over the debtor and its financial and economic activities in the process of its rehabilitation and the execution of the restructuring plan. Meanwhile, it should be noted that one of the conditions of the approved restructuring plan may be a condition for replacing the corporate management of the debtor by other managers specially involved in the procedure, independent from the beneficiaries of the debtor. Consequently, in addition to the obvious advantages for the debtor, in accordance with its content, the restructuring procedure establishes certain restrictions for the debtor, which are primarily aimed at ensuring the interests of its creditors.

An essentially similar situation is observed in French legislation, which directs business entities to use the competitive procedure for preserving an enterprise, which is beneficial both for economic turnover and for the debtor.

The change in the concept of German insolvency law, which aims not so much to liquidate the insolvent debtor, but rather to rehabilitate them, is also borrowed from Chapter 11 of the US Bankruptcy Code. At the same time, the German legislator "built" the sanation procedure into the national legislation in such a way that it is not an alien element, but fully corresponds to its spirit. The sanation procedures can be extrajudicial and judicial. Extrajudicial procedures enable to rehabilitate the debtor at earlier stages of the crisis. Reforming of the legislation in 2011 is focused on expanding the use of transmitted sanation [12]. The sanation plan procedure is considered to be the best legal remedy for rehabilitating an entity [13]. This procedure applies to insolvent entities capable of sanation [14]. The sanation plan allows to move to the deregulation of the insolvency relationship by the agreement between the debtor and creditors, which leads to the termination of the 
insolvency procedure. Therefore, the sanation procedure is recognized as an analogue of an amicable agreement [15]. After the restructuring of debts, the entity continues its activities, and the implementation of the sanation plan is monitored. Another feature of the German law is that the content of the insolvency procedure is determined by creditors. The procedure can combine the elements of sanation and liquidation at the same time, or it can be exclusively sanation, while remaining a single procedure.

\section{Conclusion}

All rehabilitation procedures provided for by the Russian bankruptcy law in relation to debtors - legal entities as main producers and taxpayers, essentially have the same goal - to restore the debtor's solvency by settling accounts payable in one legal form or another.

The key elements of the Russian model of the debtor's rehabilitation procedure, taking into account the comparative-legal analysis, should be the following: 1) providing the opportunity to enter the single rehabilitation procedure only for working bona fide legal entities - debtors; 2) retention of the powers of the debtor during the restructuring procedure to handle its corporate management, unless another corporate management procedure is properly agreed upon in the restructuring plan; 3) solving the most important issues of the restructuring procedure, as a rule, by reaching an agreement between the main participants in the procedure - the debtor, the beneficiaries of the debtor and various classes of creditors (the use of enforcement mechanisms (cramdown) should be available when other ways of negotiating in the established legal form have been exhausted).

\section{References}

1. E.E. Enkova (ed.), Legal Regulation of Bankruptcy: textbook (Prospekt, Moscow, 2021)

2. K. Zweigert, H. Kötz, Einführung in die Rechtvergleichung auf demGebiete des Privatrechts (Auflage J.C.B. Mohr (Paul Siebeck), Tübingen, 1996)

3. A. Kücher, B. Feldbauer-Durstmüller, A bibliometric study of the scientific frontend Journal of Business Research, 98, 503-516 (2019). https://doi.org/10.1016/j.jbusres.2018.05.017

4. M.V. Zakharova, M.V. Voronin, The Turkish Online Journal of Design Art and Communication, 6, 2480-2484 (2016). https://doi.org/10.7456/1060NVSE/049

5. R.R. Kobenia, Vestnik of Saint Petersburg University. Law 4(11), 1022-1034 (2020). https://doi.org/10.21638/spbu14.2020.412

6. O.A. Yastrebov, R.R. Sapparov, L.A. Bukalerova, Best Practices of the States of the Romano-Germanic Legal System in Countering Bankruptcy Crimes, in E. Popkova, B. Sergi (eds.), Scientific and Technical Revolution: Yesterday, Today and Tomorrow. ISC 2019. Lecture Notes in Networks and Systems, 129 (Springer, Cham, 2020). https://doi.org/10.1007/978-3-030-47945-9_135

7. R. Blazy, S. Esquerre, International Review of Law and Economics, 66, 105984 (2021). https://doi.org/10.1016/j.irle.2021.105984

8. S. Bernstein, E. Colonnelli, X. Giroud, B. Iverson, Journal of Financial Economics, 133(3), 608-633 (2019). https://doi.org/10.1016/j.jfineco.2018.09.010

9. H.A. Alaka, L.O. Oyedele, H.A. Owolabi, Expert Systems with Applications, 94, 164-184 (2018). https://doi.org/10.1016/j.eswa.2017.10.040 
10. N. Almaskati, R. Bird, D. Yeung, Y. Lu, Advances in Accounting, 52, 100513 (2021). https://doi.org/10.1016/j.adiac.2021.100513

11. M.V. Zakharova, M.V. Voronin, Perm University. Herald. Juridical Sciences, 1, 19-45 (2019). https://doi.org/10.17072/1995-4190- 2019-43-19-45

12. J. Van Kann, R. Redeker, Pratt's Journal of Bankruptcy Law, 436 (2012)

13. E. Braun, Insolvenzordnung (InsO) mitEUInsVO (Neufassung). Kommentar 7 (Verlag C.H. Beck, München, 2017)

14. R. Bork, Einführung indasInsolvenzrecht, in ReinhardBork, 8 (2017)

15. P. Gottwald (ed.), Insolvenzrechthandbuch (Verlag C.H. Beck., München, 2010) 